\title{
Gastric cell c-AMP stimulating autoantibodies in duodenal ulcer disease
}

\author{
F DE LAZZARI, R MIRAKIAN, L HAMMOND, C VENTURI, \\ R NACCARATO, AND G F BOTTAZZO
}

From the Department of Immunology, The Middlesex Hospital Medical School, London and the Department of Gastroenterology, University of Padua Medical School, Padua, Italy

SUMMARY Gastric cell c-AMP stimulating antibodies (GCS-Ab) were studied in 30 patients with duodenal ulcer (DU) disease. Semipurified immunoglobulin (Ig) preparations from 13/30 patients stimulated c-AMP production in parietal cell enriched gastric cell suspensions obtained from male guinea pig stomachs. Maximum stimulation (varying between 260 and $547 \%$ ) was reached after four hours incubation with 2 and $4 \mathrm{mg} / \mathrm{ml} \mathrm{Ig} \mathrm{concentrations.} \mathrm{The} 13$ patients with gastric cell stimulating antibodies (GCS-Ab), all male patients, developed the disease at a younger age (nine of 13 under the age of 30), had a longer duration of symptoms (mean 18.4 years), and had a higher incidence of DU in their families $(61 \%)$. Eight of $13(61 \%)$ in the GCS-Ab' group did not respond to anti-H2-R drugs, whereas in the negative patients only three of $17(18 \%)$ were classified as 'nonresponders'. Remarkably few conventional autoantibodies were detected in our series. Gastric cell stimulating antibodies are a new addition to the growing list of receptor antibodies in human diseases and the described in vitro test should provide an easier tool for screening large populations.

Duodenal ulcer (DU) is a heterogenous disorder in which ethnic, genetic, and environmental factors contribute to the spectrum of the known pathophysiological abnormalities and the fluctuating clinical course..$^{1-3}$ Acid hypersecretion is a well established feature in about one third of the cases but its abnormal mechanism of production and the accompanying mucosal hyperplasia are not understood. Up to $80 \%$ of duodenal ulcers heal after treatment with antihistamine 2-receptor (H2-R) drugs such as cimetidine, thus indicating the importance of histamine in stimulating gastric acid secretion in these patients. ${ }^{2}$

Stimulation of $\mathrm{H} 2-\mathrm{R}$ by histamine leads to increased production of c-AMP through the adenylcyclase pathway. ${ }^{+}$A similar response is observed when receptors on the surface of endocrine cells combine with hormones or with autoantibodies that mimic hormone action. The c-AMP stimulation test is one of the assays of choice for the determination

Address for correspondence: Dr G F Bottazzo. Department of Immunology, The Middlesex Hospital Medical School, 40-50 Tottenham Street. L.ondon W1. Received for publication 2 July 1987 of thyroid stimulating antibodies in Graves' thyrotoxicosis. 'By analogy with Graves' disease it is likely that some cases of gastric mucosal hyperplasia and hypersecretion may be associated with c-AMP stimulating autoantibodies. The association between thyroid and gastric autoimmunity is well recognised. Acid hypersecretion or duodenal ulcer have been described in members of families in which the probands were affected by thyroid autoimmune diseases or atrophic gastritis. ${ }^{7-4}$

Experiments on rats further substantiate the hypothesis 10 "that immunological abnormalities may contribute to the pathogenesis of the disease. When rats were injected with immunoglobulin preparations from duodenal ulcer patients there was a two to five fold increase in gastric acid secretion two hours after injection..$^{1213}$ The reaction was organ-specific and pretreatment with cimetidine could block the effect of patient antibodies.

The present study describes the development of an in vitro stomach bioassay system for the demonstration of c-AMP stimulation by semipurified immunoglobulins (Igs) from patients with duodenal ulcers. Positive results were obtained in about half of the 
Table 1 Selection of duodenal ulcer patients for gastric stimulating immunoglobulin assays

\begin{tabular}{|c|c|c|c|c|c|c|}
\hline \multirow{2}{*}{$\begin{array}{l}\text { Patient groups } \\
\text { Max acid output } \\
\text { (6 } \mu g / \text { kg pentagastrin) }\end{array}$} & \multirow{2}{*}{$\begin{array}{l}\text { Fasting serum } \\
\text { pepsinogen I }\end{array}$} & \multicolumn{2}{|c|}{ Numberstested } & \multirow{2}{*}{$\begin{array}{l}\text { Mean ages } \\
\text { (range, years) }\end{array}$} & \multicolumn{2}{|c|}{$\begin{array}{l}\text { Non-responders } \\
\text { to anti-H2-R drugs }\end{array}$} \\
\hline & & $M$ & $F$ & & $M$ & $F$ \\
\hline $1 \mathrm{High}$ & high & 12 & 0 & $44 \cdot 6(28-60)$ & 6 & 0) \\
\hline 2 High & normal & 12 & 2 & $47 \cdot 6(30-64)$ & 3 & 0 \\
\hline 3 Normal & high & 1 & 0 & 51 & 1 & 0 \\
\hline \multirow{2}{*}{4 Refused studies } & high & 3 & 0 & $53(42-70)$ & 1 & 0 \\
\hline & Total & 28 & 2 & $47(28-70)$ & 11 & 0 \\
\hline
\end{tabular}

cases studied, thus adding new evidence that immunological mechanisms may contribute to the pathogenesis of the disease in at least a subgroup of patients.

\section{Methods}

\section{CHOICE OF PATIENTS}

The 30 patients included in the study were recruited and followed up in one clinic (Department of Gastroenterology, University of Padua), and all had longstanding recurrent duodenal ulcer disease repetitively diagnosed by endoscopy. We excluded patients with previous gastric operations or alchohol abuse, and cases treated with steroids, aspirin, or other anti-inflammatory drugs. There were 28 men and two women with a duration of disease varying between two and 41 years; the age at onset was 20 to 53 years ( $<30$ years in 15/30 cases). A detailed family history was obtained from all patients. Ten families had other members with DU and five patients reported first degree relatives with less well defined gastric disorders. Twelve patients were non-smokers and the others admitted to smoking between 10-20 cigarettes per day. Associated disorders included: one previous thyroidectomy for non-toxic nodule, two cases with allergic rhinitis and one with nephrolithiasis. Eleven patients still had active ulcer after four to six weeks of treatment with cimetidine $(400 \mathrm{mg}$ twice a day) or ranitidine ( $150 \mathrm{mg}$ twice a day) and were considered as non-responding to anti-H2- $\mathrm{R}$ drugs.

\section{GASTRIC FUNCTION TESTS}

All the tests were carried out and the different hormonal and biochemical parameters measured in one laboratory (Department of Gastroenterology, University of Padua).

Basal acid output (BAO) was estimated for the first basal hour in 27/30 patients (normal adult value: $4 \pm 1 \mathrm{mmol} / \mathrm{h}$; DU value: $6 \cdot 3 \pm 0 \cdot 4 \mathrm{mmol} / \mathrm{h})$, whereas

Table 2 Clinical features and gastric function in 13 duodenal ulcer patients with gastric cell stimulating antibodies (GCS-Ab)

\begin{tabular}{|c|c|c|c|c|c|c|c|c|c|c|c|c|}
\hline NoCase & $\begin{array}{l}\text { Sexl } \\
\text { age }\end{array}$ & $\begin{array}{l}\text { Age } \\
\text { of } \\
\text { onset }\end{array}$ & $\begin{array}{l}\text { Duration } \\
\text { of disease } \\
\text { years }\end{array}$ & $\begin{array}{l}c-A M P \% \\
\text { above } \\
\text { control } \\
(109 \pm 31.3)\end{array}$ & $\begin{array}{l}\text { Basal acid } \\
\text { output } \\
\text { mmol/h } \\
(<6)\end{array}$ & $\begin{array}{l}\text { Maximal } \\
\text { acid } \\
\text { output } \\
\text { mmol/h } \\
(27 \pm 11 \cdot 6)\end{array}$ & $\begin{array}{l}\text { Serum } \\
\text { pepsinogen } \\
-I \\
(51 \cdot 5 \pm 20 \cdot 8 \\
\mathrm{ng} / \mathrm{ml})\end{array}$ & $\begin{array}{l} \\
\text { Family } \\
\text { history }\end{array}$ & $\begin{array}{l}\text { Resistance } \\
\text { to anti- } H_{2} \\
\text { drugs }\end{array}$ & $\begin{array}{l}\text { Complica- } \\
\text { tions }\end{array}$ & $\begin{array}{l}\text { Smoker } \\
\text { cig/day }\end{array}$ & Remarks \\
\hline $1 \mathrm{AC}$ & $\mathrm{M} / 58$ & 40 & 18 & 547 & $2 \cdot 1$ & $38 \cdot 7$ & 164 & none & none & none & 15 & $\begin{array}{l}\text { Relapsed after } \\
\text { therapy withdraw }\end{array}$ \\
\hline $3 \mathrm{AG}$ & $\mathrm{M} / 55$ & 40 & 15 & 504 & $4 \cdot 3$ & $4(0) \cdot()$ & 95 & none & cimetidine & none & 20 & Microhaematuria \\
\hline $4 \mathrm{FM}$ & $\mathrm{M} / 57$ & 30 & 28 & 496 & $16 \cdot 5$ & $64 \cdot 5$ & 235 & bDU & none & none & - & - \\
\hline $5 \mathrm{TT}$ & $\mathrm{M} / 34$ & 20 & 14 & 383 & $11 \cdot 4$ & $67 \cdot 8$ & 224 & us DU & cimetidine & none & 15 & - \\
\hline $6 \mathrm{RF}$ & $\mathrm{M} / 34$ & 20 & 14 & 343 & $2 \cdot()$ & $44 \cdot 1$ & 57 & bDU & ranitidine & bleeding & - & - \\
\hline $7 \mathrm{BZ}$ & $\mathrm{M} / 44$ & 29 & 15 & 311 & $1 \cdot 3$ & $52 \cdot()$ & 113 & $\mathrm{fGU}$ & cimetidine & none & 20 & 一 \\
\hline $8 \mathrm{GC}$ & $\mathrm{M} / 42$ & 30 & 12 & 303 & test & refused & 280 & $\begin{array}{l}\text { 3bs } \\
\text { DU }\end{array}$ & none & none & 20 & - \\
\hline $9 \mathrm{VM}$ & $\mathrm{M} / 51$ & 24 & 28 & 290 & $14 \cdot 3$ & $65 \cdot 0$ & 210 & $\begin{array}{l}\text { fDU } \\
\text { m CaSt }\end{array}$ & none & bleeding & - & - \\
\hline $10 \mathrm{MGC}$ & $\mathrm{M} / 38$ & 24 & 14 & 273 & $15 \cdot 7$ & $95 \cdot 6$ & 245 & none & ranitidine & perforation & $1-$ & Allergic rhinitis \\
\hline $11 \mathrm{MG}$ & $\mathrm{M} / 50$ & 29 & 21 & 268 & $8 \cdot 8$ & $38 \cdot 4$ & 112 & $\mathrm{fDU}$ & cimetidine & blecding & 15 & - \\
\hline $12 \mathrm{OR}$ & $M / 60$ & 42 & 18 & 275 & $13 \cdot 1$ & $64 \cdot 4$ & 112 & f DU & cimetidine & perforation & 10 & - \\
\hline $13 \mathrm{GP}$ & $\mathrm{M} / 35$ & 33 & 2 & 260 & 0.4 & $52 \cdot 9$ & 96 & none & none & none & 15 & - \\
\hline
\end{tabular}

$f=$ father; $m=$ mother $;(s)=$ brother $(s) ;$ us= uncles; $D U=$ duodenal ulcer $; G U=$ gastric ulcer; CaSt $=$ Carcinoma of the stomach . 
0-60 minutes maximal acid output (MAO) was measured in the same subjects after stimulation with $6 \mu \mathrm{g} / \mathrm{kg}$ of pentagastrin (Gastrodiagnost, Merck) (normal adult value: $27 \pm 11.6 \mathrm{mmol} / \mathrm{h}$; DU value: $46 \cdot 3 \pm 1.6 \mathrm{mmol} / \mathrm{h})$. The concentration of serum Pepsinogen group I (PGI: Pepsik kit, Sorin, Saluggia, Varese, Italy) was measured in all 30 cases (normal value: $51 \cdot 5 \pm 20 \cdot 8 \mathrm{ng} / \mathrm{ml}$, DU value: $91 \cdot 3 \pm 40 \cdot 1 \mathrm{mg} / \mathrm{ml}$ ). Fluctuations of serum PGI concentrations were observed in some patients on repeated testing, but the values reported here correspond to the time when the sera were collected and subsequently used for measuring gastric cell stimulating antibodies (GCS-Ab). Total basal gastrin concentrations were assayed in all patients with commercial kits (Becton and Dickinson) (normal value: up to 100 $\mathrm{pg} / \mathrm{ml}$ ) and stimulated gastrin response was evaluated in 10 cases as a pick at two hours after a standard proteic meal (normal value: up to $250 \mathrm{pg} / \mathrm{ml}$ ).

The clinical and biochemical characteristics of the patients studied are summarised in Tables 1 to 3 .

PREPARATIONS OFGASTRIC CELL SUSPENSIONS Gastric cells were obtained from two to three months old male guinea pigs fed normally before being killed by $\mathrm{CO}_{2}$ asphyxiation. After removal of the stomach only fundal and body mucosa were subsequently used. The tissue was rinsed three times and adherent mucus was removed by a glass slide. After stripping the smooth muscle coat, the mucosa was finely minced and the cells were dispersed by stepwise digestion in collagenase $(0.75 \mathrm{mg} / \mathrm{ml}$ Worthington Type IV dissolved in BSS supplemented with $0 \cdot 2 \%$ bovine serum albumin, $25 \mathrm{mM}$ HEPES, $40 \mu \mathrm{g} / \mathrm{ml}$ gentamycin, $100 \mathrm{U} / \mathrm{ml}$ penicillin; $\mathrm{pH} \mathrm{7.2).} \mathrm{Three}$ periods of 10,30 , and 10 min were sufficient to obtain small clumps or single cells for preparing 60-90 tubes, each containing $1.5-5 \times 10^{5}$ cells, as estimated by haemocytometer counts. The cells were harvested and filtered through a $200 \mathrm{~mm}$ nylon mesh to remove coarse fragments. The percentage of parietal cells in each suspension was estimated by the size and shape of the cells and by indirect immunofluorescence (IFL) staining with parietal cell antibody positive sera on air-dried smears. Parietal cell enriched suspensions of $45-55 \%$ were regularly obtained by selecting the right portion of the gastric mucosa and additional slow centrifugation step. Viability was assessed by differential staining with acridine orange/ ethidium bromide under ultraviolet light and it was in the order of 90 to $95 \%$.

\section{IMMUNOGLOBULIN (Ig) PREPARATIONS}

Sera from the 30 DU patients were precipitated with $1.64 \mathrm{~mol} / \mathrm{l}$ ammonium sulphate followed by extensive dialysis against phosphate buffered saline, $\mathrm{pH} 7 \cdot 2$. Protein content was estimated by spectrophotometry. A similar procedure was used to prepare Igs from sera of 20 healthy laboratory staff. They were symptom free, had serum PG1 concentrations within

Table 3 Clinical features and gastric function in 17 duodenal ulcer patients negative for gastric cell stimulatory antibodies $(G C S-A)$

\begin{tabular}{|c|c|c|c|c|c|c|c|c|c|c|c|}
\hline No Case & $\begin{array}{l}\text { Sex/ } \\
\text { age }\end{array}$ & $\begin{array}{l}\text { Duration } \\
\text { disease } \\
\text { years }\end{array}$ & $\begin{array}{l}c-A M P \% \\
\text { above } \\
\text { control } \\
(109 \pm 31.3)\end{array}$ & $\begin{array}{l}\text { Basal acid } \\
\text { output } \\
\text { mmol/h } \\
(<6)\end{array}$ & $\begin{array}{l}\text { Maximal } \\
\text { acid } \\
\text { output } \\
\text { mmol/h } \\
(27 \pm 11 \cdot 6)\end{array}$ & $\begin{array}{l}\text { Serum } \\
\text { pepsinogen } \\
-I \\
(51 \cdot 5 \pm 20 \cdot 8 \\
\mathrm{ng} / \mathrm{ml})\end{array}$ & $\begin{array}{l}\text { Family } \\
\text { history }\end{array}$ & $\begin{array}{l}\text { Resistance } \\
\text { to } \\
\text { anti- } \mathrm{H}_{2}-\mathrm{R} \\
\text { drugs }\end{array}$ & $\begin{array}{l}\text { Complica- } \\
\text { tions }\end{array}$ & $\begin{array}{l}\text { Smoker } \\
\text { cig/day }\end{array}$ & Remarks \\
\hline $1 \mathrm{BS}$ & $\mathrm{M} / 29$ & 23 & 107 & $1 \cdot 5$ & $81 \cdot 5$ & 70 & f DU & none & none & - & - \\
\hline $2 \mathrm{ZF}$ & $\mathrm{F} / 20$ & 10 & 108 & $6 \cdot 1$ & $41 \cdot 1$ & 77 & none & none & blecding & - & Allergic rhinitis \\
\hline $4 \mathrm{GG}$ & $\mathrm{M} / 48$ & 4 & 94 & $12 \cdot 4$ & $44 \cdot 2$ & 96 & none & none & none & - & - \\
\hline $5 \mathrm{PG}$ & $\mathrm{M} / 51$ & 7 & 158 & $1 \cdot 5$ & 77 & 61 & none & none & none & 10 & - \\
\hline $6 \mathrm{VD}$ & $\mathrm{M} / 33$ & 4 & 120 & $0 \cdot 6$ & $42 \cdot 9$ & 125 & none & none & bleeding & 15 & - \\
\hline 7 PA & $\mathrm{M} / 24$ & 12 & 123 & $6 \cdot 1$ & $46 \cdot 1$ & 85 & none & none & blecding & 15 & - \\
\hline $8 \mathrm{MD}$ & $\mathrm{M} / 22$ & 6 & 145 & $4 \cdot 8$ & $62 \cdot 2$ & 149 & u DU & none & none & - & - \\
\hline $9 \mathrm{TE}$ & $M / 43$ & 21 & 104 & $3 \cdot 7$ & $44 \cdot 4$ & 78 & b DU & cimetidine & none & - & - \\
\hline $10 \mathrm{LR}$ & $\mathrm{M} / 47$ & 1 & 115 & test & refused & 133 & $\mathrm{fGU}$ & none & bleeding & - & Thyroidectomy \\
\hline $11 \mathrm{FC}$ & $\mathrm{M} / 29$ & 2 & 168 & $8 \cdot 1$ & $78 \cdot 9$ & 119 & $\frac{\mathrm{mb}}{\text { Gastr }}$ & none & blecding & 20 & - \\
\hline $12 \mathrm{BG}$ & $\mathrm{M} / 47$ & 15 & 95 & $11 \cdot 7$ & $90 \cdot 2$ & 76 & none & none & none & 10 & Renal tuberculosis \\
\hline $13 \mathrm{BS}$ & $\mathrm{M} / 20$ & 26 & 148 & 0.9 & $40 \cdot 5$ & 160 & $\mathrm{mGU}$ & ranitidine & none & 10 & - \\
\hline $14 \mathrm{MO}$ & $\mathrm{M} / 53$ & 3 & 158 & $18 \cdot 7$ & $85 \cdot 7$ & 57 & none & none & none & - & $\begin{array}{l}\text { Pulmonary } \\
\text { emphysema }\end{array}$ \\
\hline $15 \mathrm{DGR}$ & $F / 34$ & 13 & 130 & 1 & 4()$\cdot 2$ & 63 & none & none & none & - & - \\
\hline $16 \mathrm{LA}$ & $\mathrm{M} / 40$ & 6 & 132 & 0.7 & $42 \cdot 7$ & 93 & none & none & none & - & - \\
\hline $17 \mathrm{BG}$ & $M / 36$ & 2 & 102 & 0.9 & $39 \cdot 9$ & 81 & none & none & none & - & - \\
\hline
\end{tabular}

$\mathrm{f}=$ father $; \mathrm{m}=$ mother $; \mathrm{b}=$ brother $; \mathrm{u}=$ uncle. $\mathrm{DU}=$ duodenal ulcer $; \mathrm{GU}=$ gastric ulcer Gastr=gastritis . 
the normal range and no family history of gastroduodenal disorders.

\section{C-AMP ESTIMATIONS}

Gastric cells were placed in Falcon tubes at concentrations of $1.5 \times 10^{5}$ parietal cells and kept at $37^{\circ} \mathrm{C}$ for at least two hours before starting the test procedure. In initial experiments a different number of cells, several concentrations of reagents and Igs, and time of incubations were tried to optimise the method. cAMP estimations were carried out by the alcohol extraction method ${ }^{5}$ and measured in duplicate using the Amersham TRK 423 kits. Control tubes containing only $40 \mu \mathrm{l} 5 \mathrm{~m} \mathrm{M}$-3-isobutyl-1-methyl-xanthine (IBMX-SIGMA) were interspersed at regular intervals among tests and control Igs to overcome unavoidable differences in the cell contents per tube. This phosphodiesterase inhibitor was added to all culture tubes to prevent degradation of accumulated c-AMP. This accumulation was expressed as $\mathrm{pmol} / \mathrm{tube}$.

\section{AUTOANTIBODY TESTS}

The patient and control sera were tested for organand non-organ specific autoantibodies by indirect IFL on sections of human stomach and other tissues $^{1516}$ or in the case of thyroid by 'established commercial haemagglutination kits (Wellcome Thymune Reagents). The DU sera were also tested for surface reactive parietal cell antibodies using indirect IFL and viable guinea pig gastric cell suspensions. ${ }^{17}$

\section{Results}

GASTRIC C-AMP STIMULATION ASSAY

To standardise the gastric cell suspensions and establish optimum conditions for parietal cell enrichment and c-AMP accumulation, standard curves were first obtained with histamine dihydrochloride (SIGMA). Maximum c-AMP stimulation was reached within 30 minutes at $10^{-3} \mathrm{M}$ being $520 \%$ above basal values, as described by other authors. ${ }^{18}$ Occasional stomachs proved to be poorly responsive to histamine stimulation and had to be discarded.

When Ig preparations were incubated with cell suspensions the conditions were quite different. No stimulation above the IBMX basal level was seen before three hours of incubation at $37^{\circ} \mathrm{C}$. Incubations of up to 16 hours were tried, but it was found that four hours produced significant results with the positive sera on repeated testing and this period was chosen for all the subsequent experiments. Increasing the amounts of Ig up to $7 \mathrm{mg} / \mathrm{ml}$ did not regularly yield a higher number of positive sera, so that we finally chose 2 and $4 \mathrm{mg} \mathrm{Ig/ml}$ to show dose related c-AMP stimulation. The basal c-AMP accumulation with IBMX only, varied from $0.5-6 \mathrm{pmol} /$ tube in cell suspensions from different animals, so we calculated histamine or Ig c-AMP stimulation as a percentage of basal accumulation. In each batch of Falcon tubes we included 5-10 IBMX tubes, 20 tubes were used for normal individual Igs in duplicate and the remaining tubes were incubated with Igs from DU patients always tested in duplicate with a constant degree of reproductibility.

The intra-assay variations were: for spontaneous cAMP release $\pm 0.9 \mathrm{pmol} / \mathrm{tube}$, and with normal Igs, 'negative' DU Igs and 'positive' DU Igs, \pm 0.09 , $\pm 0 \cdot 6$, and $\pm 0.6 \mathrm{pmol} /$ tube, respectively. The interassay variations were subject to the gastric cell preparations obtained from different animals, but there was no statistical difference in the percentage of incremental stimulation from basal level with positive and negative controls.

The test was considered positive when values were above $172 \%$ of basal c-AMP accumulation, which was the mean value plus two standard deviations of control Ig basal stimulation $(109 \pm 31 \cdot 3 \times 2)$.

Each control Ig, 'negative' DU Ig and Igs giving positive c-AMP stimulation were assayed repeatedly with different stomachs, at various concentrations (2-7 $\mathrm{mg} / \mathrm{ml})$ and incubation times; the results were reproducible. Gastrin 1-17 (SIGMA) and pentagastrin (Boeringwerke) were included as additional negative controls.

\section{C-AMP STIMULATION RESULTS IN DUODENAL ULCER PATIENTS AND CONTROLS}

The 20 normal control Igs were consistently within the range of the IBMX control and gave the same results at 2 and $4 \mathrm{mg} \mathrm{Ig} / \mathrm{ml}$ up to 16 hours. In contrast, the Igs from 13/30 DU patients were able to stimulate the production of c-AMP in parietal cells enriched gastric cell suspensions (Figure). Eight cases were clearly positive at both 2 and $4 \mathrm{mg} / \mathrm{ml} \mathrm{Ig} \mathrm{dosages,} \mathrm{five}$ patients became positive at $4 \mathrm{mg}$ and in all 13 there was a dose related increase in c-AMP accumulation, maximum stimulation varying between $260-547 \%$. The other $17 \mathrm{DU}$ patients were classed as negative.

\section{CLINICAL CORRELATIONS}

The clinical features and gastric function tests for the 13 patients with positive c-AMP assays are shown in Table 2 and the 17 negative cases are listed in Table 3. The positive patients, all men, developed the disease at a younger age with symptoms under the age of 30 in nine. There was a family history of DU in eight and an additional patient had a mother with gastric ulcer. There was a high proportion (eight of 13) of poor responders to anti-H2R drugs, bleeding or perforations were noted in five cases and nine patients were 


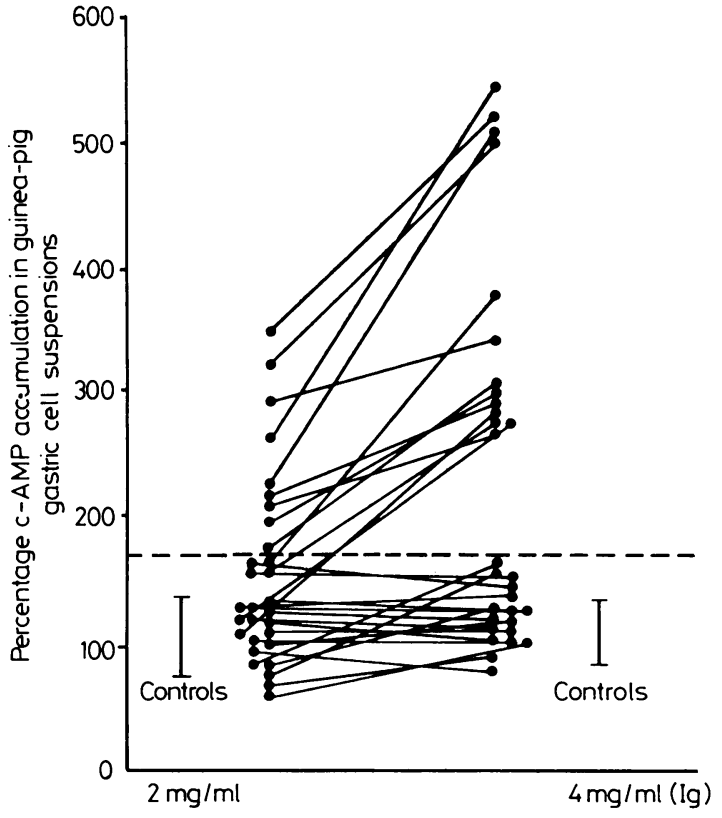

Figure Represents dose dependent stimulatory responses of individual patients and controls. Lines between symbols show increased $c$-AMP stimulation on doubling the dose of Ig added to the same guinea pig stomach cultures after four hours incubation. Dotted line represents the mean plus two $S D$ of values obtained with control Igs as compared with IBMX only. 2-4 mg Igs: Control Igs $=N S$, Negative DU Igs $=$ NS, Positive DU IgG $p=0.001$ (Student's t test).

smokers. Over half the patients had very high MAO values. Although the PGl concentrations were above the normal in 10 of these patients, five of them showed fluctuations into the normal range on repeated testing.

The c-AMP negative group contained a lower proportion of early onset cases (six of 17 aged under 30), less familial DU disease and fewer patients with high acidity or raised serum PG1 concentrations. Finally, there were half as many smokers in this second group, clearly showing the multifactorial nature of DU disease in its causative as well as its aggravating aspects.

Basal gastrin concentrations were normal in all the patients studied and they did not rise abnormally in the 10 patients who underwent a meal stimulation test. The latter were equally distributed between the GCS-Ab positive and negative groups. (Table 4).

\section{OTHER AUTOANTIBODIES}

There were remarkably few conventional antibodies in the DU cases and no difference was found between those who showed c-AMP stimulating reactions and the negatives. Traces of antinuclear antibodies were
Table 4 Comparison of DU patients with and without gastric c-AMP stimulating antibodies

\begin{tabular}{|c|c|c|c|c|}
\hline \multirow{3}{*}{$\begin{array}{l}\text { Clinical features } \\
\text { and gastric function }\end{array}$} & \multicolumn{4}{|c|}{ Gastric cellstimulating autoantibodies } \\
\hline & \multicolumn{2}{|c|}{ Positive $(n=1.3)$} & \multicolumn{2}{|c|}{ Negative $(n=17)$} \\
\hline & $n$ & $(\%)$ & $n$ & $(\%)$ \\
\hline $\mathrm{M} / \mathrm{F}$ & \multicolumn{2}{|l|}{$13 /()$} & \multicolumn{2}{|l|}{$15 / 2$} \\
\hline $\begin{array}{l}\text { Age at onset of DU: mean } \\
\text { (range in years) }\end{array}$ & \multicolumn{2}{|l|}{$\begin{array}{l}30 \cdot() \\
\quad(20-40)\end{array}$} & \multicolumn{2}{|l|}{$\begin{array}{l}36 \cdot 7 \\
\quad(20-53)\end{array}$} \\
\hline $\begin{array}{l}\text { Duration of discase:mean } \\
\text { (range in years) }\end{array}$ & \multicolumn{2}{|l|}{$\begin{array}{l}18 \cdot 4 \\
(2-41)\end{array}$} & \multicolumn{2}{|l|}{$\begin{array}{l}9 \cdot 1 \\
(1-26)\end{array}$} \\
\hline Family history of DU & 8 & $(61)$ & 2 & $(12)$ \\
\hline \multicolumn{5}{|l|}{ Complications: } \\
\hline Bleceding & 3 & $(38)$ & 6 & $(35)$ \\
\hline Perforation & 2 & & () & \\
\hline Smokers & 10 & (77) & 6 & $(35)$ \\
\hline $\begin{array}{l}\text { Non-responders to anti- } \\
\mathrm{H}_{2} \mathrm{R} \text { drugs }\end{array}$ & 8 & $(61)$ & 3 & $(18)$ \\
\hline $\begin{array}{l}\text { High basal acid output } \\
(>6 \mathrm{mmol} / \mathrm{h})\end{array}$ & $6 / 11^{*}$ & $(54)$ & $6 / 16 \dagger$ & $(37)$ \\
\hline $\begin{array}{l}\text { High maximal acid output } \\
\qquad(>60 \mathrm{mmol} / \mathrm{h})\end{array}$ & $5 / 11^{*}$ & $(45)$ & $6 / 16 \div$ & $(37)$ \\
\hline $\begin{array}{l}\text { High pepsinogen } \mathrm{l}(>\mathrm{l}(0) \\
\mathrm{ng} / \mathrm{ml})\end{array}$ & 10 & $(77)$ & 6 & $(35)$ \\
\hline
\end{tabular}

*Two patients refused the test: tone patient refused the test.

seen in four patients, weak parietal cell IFL was obtained with undiluted serum in two patients in the c-AMP negative group and thyroid antibodies were all negative. When viable guinea pig gastric cells were examined for surface IFL reactions, only faint traces of staining could be seen in nine of the DU sera of whom five stimulated c-AMP and four were negative.

\section{Discussion}

The work on duodenal ulcer disease presented in this paper followed a pattern of development similar to earlier studies in thyrotoxicosis. The first clue to the existence of stimulating autoantibodies in Graves' disease was obtained when animals injected with the patients' sera showed a delayed response of glandular stimulation when compared with pituitary thyroid stimulating hormone (TSH). By analogy with the long acting thyroid stimulator (LATS) test in mice, ${ }^{19}$ Dobi and Lenkey's gastric experiments convincingly showed a delayed peak of gastric acid secretion in vivo in the rat, when comparing histamine curves with the responses to intravenous injections of Igs from patients with hypersecretory forms of DU disease. ${ }^{13}$ In the case of thyrotoxicosis, more direct evidence of thyrocyte activation was obtained when reliable and clinically applicable in vitro c-AMP stimulation assays were developed using cell membrane preparations ${ }^{21}$ or viable cell suspensions. ${ }^{21}$ The new gastric c-AMP bioassay described here will similarly prove valuable as a step towards the 
standardisation of stimulatory antibodies in patients with DU disease and should help clarify some aspects of the heterogeneity in the DU syndrome when applied prospectively in larger numbers of patients.

It is probable that gastric parietal cells are primarily stimulated in the c-AMP assay despite the presence of a mixed cell population in the suspensions we employed. The presence of Igs acting on chief cells rather than parietal cells cannot be excluded as the secretion of PGI is partly dependent on the c-AMP pathway under acid conditions or when chief cells are stimulated by secretin (or VIP). ${ }^{22}$ We failed to obtain clear cut accumulation of c-AMP in the guinea pig gastric cell suspension, however, unless the parietal cell content was at least $50 \%$. There are now methods for parietal cell enrichment up to $90 \%$ using dog stomach,,$^{23}$ and this improved separation should help to dissect out the Ig stimulatory effects on the two principal types of gastric mucosal cells.

Dobi and Lenkey ${ }^{1.3}$ showed that the injected rats secreted acid and that the stimulatory effect of the DU Igs could be inhibited by pretreatment of the animals with cimetidine. This remains to be studied in cell suspensions. Interestingly, however, more than half our GCS-Ab positive cases did not respond to anti-H2-R drugs. These results might indicate occupancy of the target receptor by antibody in vivo and emphasise the potential prognostic value of the test in predicting a positive response to treatment in DU patients.

Although column purified Igs were not used in the present study, we are confident that c-AMP accumulation was caused by the effect of antibodies. Basal and stimulated serum gastrin was not raised in our patients and even if small amounts were present, this hormone acts on parietal cells via $\mathrm{Ca}^{++}$-dependent membrane activation and not through adenyl cyclase and c-AMP. ${ }^{7}$ In our hands gastrin did not increase c-AMP accumulation in guinea pig gastric suspensions. Histamine and prostaglandins are very labile and would be unikely to withstand extensive manipulations.

So far guinea pig stomachs have proved to be the best tissue substrate for measuring GCS-Ab. Inconsistent results were obtained with rat preparations, which are also known to be less responsive to histamine stimulation..$^{2+}$ Interspecies variations have to be taken into account for future standardisation of the test and human gastric parietal cells may detect higher numbers of positive patients if species specificity is important, as previously shown when measuring thyroid stimulating Igs in the LATSprotector test. ${ }^{25}$ The ideal substrate for the in vitro c-AMP test could turn out to be purified human parietal cell basolateral membranes, ${ }^{23}$ prepared from fresh stomachs obtained from deceased donors when their kidneys are being removed for transplantation.

The majority of cases with stimulatory Igs had raised MAO's and serum PGl values. The three exceptions $(3,6,13$ in Table 2$)$, who had normal or borderline values for $\mathrm{BAO}$ and $\mathrm{PG} 1$, can perhaps be explained by a better response to anti-H2-R treatment at the time of the investigation, to the fluctuations known to occur on repeating gastric function tests in DU disease or to variation in titre of GCS-Abs.

We may now ask how stimulatory autoimmunity contributes to the pathogenesis of DU and draw parallels with thyroid disease. In thyroid autoimmunity there is a remarkable overlap between destructive and stimulatory features, and women are mainly affected." In pernicious anaemia the sex ratio is more equal; in DU there is total reversal, especially in hypersecretors who are usually men. Fluorescent antibody tests in the present report and in previous population studies suggest that destructive and stimulatory phenomena at the level of the stomach are not strongly correlated, as indicated by the low prevalence of parietal cell antibodies in DU patients when compared with healthy controls. This apparent lack of clinical and immunological correlation could be explained by the fact that gastric physiology is regulated by many more hormones and factors than the thyroid gland; stimulatory gastric autoimmunity may therefore turn out to be more complex and difficult to dissect."

In conclusion the present data support the concept that, like thyroid autoimmunity, stimulatory immunological phenomena in the stomach do exist. The development of more sensitive and automated bioassays will better define the precise role of autoimmunity in the pathogenesis of certain forms of duodenal ulcer disease.

We would like to thank Professor Deborah Doniach for many useful discussions and for help with the ms, and Professor Roitt for his continuous support. The late Professor R Farini gave inspiration and clinical support during the initial phase of this work. Drs $M$ Pleani and F Di Mario were responsible for the gastric function tests and we also thank our medical students and nursing sisters, especially Ms Angela Tonello, for their valuable assistance with the patients studied in Padua. FDL was supported by grants from Smith Kline and French, Zyma, Glaxo, and the 'Roberto Farini' Association.

\section{References}

1 Grossman MI, Kurata JH, Rotter JI, et al. Peptic ulcer: new therapies, new diseases. Ann Intern Med 1981; 95: 609-27. 
2 Lam S. Pathogenesis and pathophysiology of duodenal ulcer. Clin Gastroenterol 1984; 13: 447-72.

3 Rotter JI, Rimoin DL. Peptic ulcer disease - A heterogeneous group of disorders? Gastroenterology 1977; 73: 604-7.

4 Rees WDWM, Turnbeg LA. Biochemical aspects of gastric secretion. Clin Gastroenterol 1981; 10: 521-54.

5 Bidey SP, Emmerson JM, Marshall NJ, Ekins RP. Characterization of thyroid-stimulation immunoglobulin-induced cyclic AMP accumulation in the rat thyroid cell strain FRTL-5 potentiation by forskolin and calibration against reference preparations of thyrotrophin. J Endocrinol 1985; 105: 7-15.

6 Bottazzo GF, Doniach D. Polyendocrine autoimmunity: an extended concept. In: Volpe $\mathrm{R}$, ed. Autoimmunity and endocrine disease. New York; M Dekker Inc, 1985: 375-403.

7 Taylor IL, Calam J, Rotter JI, et al. Family studies in hypergastrinemic hyperpepsinogenemic I duodenal ulcer. Ann Intern Med 1981; 95: 421-5.

8 Varis K, Samloff IM, Tiilikainen A, et al. Gastritis in first degree relatives of pernicious anemia gastric patients and controls. In: Rotter SL, Samloff IM, Rimoin DL, eds. Genetics and heterogeneity of common gastrointestinal disorders. New York: Academic Press, 1980: 177-91.

9 Lamers C, Diemel C, Froeling P, Jansen J. Heredity of hypergastrinemic hyperchlochydria syndrome. In: Rotter JL, Samloff IM, Rimoin DL, eds. Genetics and heterogeneity of common gastrointestinal disorders. New York: Academic Press, 1980: 81-9.

10 Rotter JI, Heiner DC. Are there immunologic forms of duodenal ulcer? J Clin Lab Immunol 1982 7: 1-6.

11 Kirk EM. Could chronic peptic ulcers be localized areas of acid susceptibility generated by autoimmunity. Lancet 1986; i: 772-5.

12 Dobi S, Petranyi G. Secretagogue globulins in the blood of duodenal ulcer patients. Acta Med Acad Sci Hung 1973; 30: 205-10.

13 Dobi S, Lenkey B. Role of secretagogue immunoglobulin in gastric acid secretion. Acta Physiol Acad Sci Hung 1982; 60: 9-25.

14 Batzri S, Gardne JD. Cellular cyclic AMP in dispersed mucosal cells from guinea pig stomach. Biochim Biophys Acta 1978; 541: 181-9.

15 Scherbaum WA, Mirakian R, Pujol-Borrell R, Dean BM, Bottazzo GF. Immunocytochemistry in the study and diagnosis of organ-specific autoimmune disease. In: Polak Sm, Van Norden S, eds. Immunocytochemistry: modern methods and applications. Bristol: J Wright, 1986: 456-76.

16 Schebaum WA, Blaschek M, Berg PA, Doniach D, Bottazzo GF. Spectrum and profiles of non-organspecific autoantibodies in autoimmune diseases. In: Polak SM, Van Norden, eds. Immunocytochemistry: modern methods and applications. Bristol: J Wright, 1986: 477-91.

17 Masala C, Smurra G, Di Prima MA, Amendolea MA, Celestino D, Salsano F. Gastric parietal cell antibodies demonstration by immunofluorescence of their reactivity with the surface of gastric parietal cells. Clin Exp Immunol 1980; 41: 271-80.

18 Wollin A, Soll AH, Samloff IM. Actions of histamine, secretin and $\mathrm{PGE}_{2}$ on cyclic AMP production by isolated canine fundic mucosal cells. Am J Physiol 1979; 65: E437-43.

19 McKenzie JM, Zakarija M. The thyroid stimulating antibody of Graves' disease Part I general concepts and assay materials. In: Chayen J, Bitensky L, eds. Cytochemical bioassays, techniques and clinical applications. New York: Marcel Dekker Inc, 1983: 135-43.

20 Orgiazzi J, Williams DE, Chopra IJ, Solomon DH. Human thyroid adenyl-cyclase stimulating activity in immunoglobulin $\mathrm{G}$ of patients with Graves' disease. J Clin Endocrinol Metab 1976; 42: 341-54.

21 Bidey SP, Marshall NJ, Ekins RP. Bioassay of thyroid stimulating immunoglobulins using human thyroid cell cultures: optimization and clinical assessment. Clin Endocrinol 1983; 18: 193-206.

22 Raufman J-P, Sutlif VE, Kasbekar DK, Jensen RT, Gardner JD. Pepsinogen secretion from dispersed chief cells from guinea pig stomach. Am J Physiol 1984; 247: G95-104.

23 De Aizpurua HJ, Ungar U, Toh BH. Flow microfluorimetric analysis of autoantibody reactions with parietal cell surface membranes in pernicious anaemia. Clin Exp Immunol 1983; 54: 404-10.

24 Holian O, Ruiz C, Bombeck CT, Nyhus LM. Comparison of c-AMP system in parietal cells from rat and guinea pig. Scand J Gastroenterol 1983; 16: 819-24.

25 Adams DD, Kennedy TH. Occurrence in thyrotoxicosis of a gammaglobulin which protects LATS from neutralization by an extract of thyroid gland. J Clin Endocrinol Metab 1967; 27: 173-7. 